\title{
Assessment of risky drinking, harmful drinking and alcohol addiction among lawyers
}

Ocena picia ryzykownego i szkodliwego oraz uzależnienia od alkoholu wśród adwokatów

\author{
1 Non-public Healthcare Institution"nMed," Krakow, Poland \\ ${ }^{2}$ Department of Environmental Medicine and Epidemiology, Faculty of Medical Sciences, Medical University of Silesia, Zabrze, Poland \\ Correspondence: Katarzyna S. Chrobak-Kasprzyk, MD, Non-public Healthcare Institution “nMed,"E. Radzikowskiego 17/2, 31-315 Krakow, Poland, tel.: +48 1262622 00, \\ e-mail: katarzyna.chrobak-kasprzyk@nmed.pl
}

${ }^{1}$ Niepubliczny Zakład Opieki Zdrowotnej nMed, Kraków, Polska

${ }^{2}$ Katedra i Zakład Medycyny i Epidemiologii Środowiskowej, Wydział Nauk Medycznych w Zabrzu, Śląski Uniwersytet Medyczny w Katowicach, Zabrze, Polska

Adres do korespondencji: Lek. med. Katarzyna S. Chrobak-Kasprzyk, Niepubliczny Zakład Opieki Zdrowotnej nMed, ul. E. Radzikowskiego 17/2, 31-315 Kraków, tel.: +48 12 62622 00,

e-mail: katarzyna.chrobak-kasprzyk@nmed.pl

Abstract Background: Not much is known about alcohol dependence, risky or harmful drinking among Polish lawyers. Studies conducted around the world have so far shown that this professional group is at a greater risk of alcohol addiction than the total population or other professional groups. Aim: The aim of this study was to determine the model of alcohol consumption among lawyers, as well as the factors influencing this phenomenon. Materials and methods: The study was conducted among 206 lawyers, including 102 women and 104 men, aged between 29 and 84 years. The AUDIT test, developed by World Health Organization, was used. Results: In the study group of lawyers, $22.33 \%$ drink in a risky and harmful manner, including nearly $3 \%$ whose score suggests alcohol addiction. It was shown that the sex criterion differentiated the alcohol consumption model among lawyers, with statistically significant higher average values obtained for men $(p=0.002)$. The study showed that the drinking model is influenced both by the marital status of respondents and whether they have children or not $(p=0.000033)$. There was no influence of weekly working hours on the alcohol use pattern $(p=0.169, r=0.10)$. An analysis using the Pearson's $r$ correlation coefficient showed a statistically significant relationship $(p=0.021)$ between age and AUDIT score. This was a low-strength negative correlation $(r=-0.16)$, i.e. AUDIT scores decreased with the age of respondents. Conclusions: This study is the first medical assessment of the prevalence of alcohol use among Polish lawyers. Lawyers are a professional group reluctant to undergo evaluation, who are at a high risk of problematic alcohol use. The study shows that there is a need for in-depth diagnosis of alcohol addiction and development of educational, preventive and therapeutic programs that take into account the specificity of the work of lawyers.

Keywords: harmful drinking, risky drinking, lawyers, addictions, alcohol, AUDIT

Wstęp: O uzależnieniu od alkoholu, piciu ryzykownym lub szkodliwym w grupie polskich adwokatów wiadomo niewiele. $Z$ badań przeprowadzonych w innych krajach wynika, że ryzyko uzależnienia jest wśród adwokatów wyższe niż w populacji ogólnej czy w innych grupach zawodowych. Cel pracy: Celami badania były określenie modelu picia alkoholu w grupie polskich adwokatów oraz identyfikacja czynników związanych z piciem. Material i metody: Badaniem objęto 206 adwokatów (102 kobiety i 104 mężczyzn) w wieku 29-84 lat. Użyto testu przesiewowego AUDIT, opracowanego przez Światową Organizację Zdrowia. Wyniki: Spośród badanych adwokatów 22,33\% pije ryzykownie lub szkodliwie, w tym u blisko 3\% wynik może wskazywać na uzależnienie. Wykazano, że płeć różnicuje model spożywania alkoholu: wyższe wartości średnich (różnica istotna statystycznie) uzyskano dla mężczyzn ( $p=0,002)$. Dowiedziono, iż na model picia mają wpływ stan cywilny i posiadanie dzieci $(p=0,000033)$. Nie wykazano korelacji między liczbą godzin pracy w tygodniu a modelem picia alkoholu $(p=0,169, r=0,10)$. Wraz ze wzrostem wieku badanych i stażu pracy malała liczba punktów w skali AUDIT $(p=0,021, r=-0,16)$. Wnioski: Prezentowane badanie jest pierwszą medyczną oceną zjawiska picia alkoholu wśród adwokatów w Polsce. Adwokaci to grupa zawodowa, która niechętnie poddaje się badaniom, a jednocześnie grupa wysokiego ryzyka problemowego używania alkoholu. Wyniki badań przesiewowych dowodzą, że istnieje konieczność pogłębionej diagnostyki w kierunku uzależnienia od alkoholu oraz stworzenia programów edukacyjnych, profilaktycznych i terapeutycznych uwzględniających specyfikę wykonywanego zawodu. 


\section{INTRODUCTION}

A ccording to the World Health Organization's (WHO) "Global status report on alcohol and health 2018," harmful use of alcohol results in about 3 million deaths annually (including $75 \%$ of men). This means that alcohol accounts for $5 \%$ of all deaths. In the context of public health, it is also very important that harmful use of alcohol is responsible for more than $5 \%$ of disease burden. Furthermore, the report showed that harmful and risky use of alcohol is the third leading risk factor of ill health and premature death in the European Union. Studies conducted in Poland have shown that people with alcohol dependence and those with harmful alcohol use account for $2 \%$ and $5-7 \%$ of the population, respectively (Moskalewicz et al., 2012).

There are few studies assessing alcohol consumption model among lawyers. Benjamin et al. (1990) showed in their screening studies among lawyers that problematic alcohol consumption is twice more common in this group compared to the general population. A questionnaire study in the USA showed that the risk of alcohol dependence, risky or harmful alcohol use accounted for $20.6 \%$ of lawyers, suggesting that this professional group is at a greater risk of addiction compared to the total population (Krill et al., 2016). In their study in a group of 486 French lawyers, Tran et al. (2007) showed alcohol abuse in $11 \%$ of men and $6 \%$ of woman, which was again higher compared to the general population.

Although the most recent study was published in 2016, the issue of alcohol consumption among lawyers is still largely unexplored. Few studies have been conducted to verify the problem empirically or statistically, especially among Polish lawyers.

The specificity of the work of lawyers involves stressful public appearances and frequent social meetings, which create many opportunities for alcohol consumption. Additionally, the attractiveness and prestige of the profession may be the reason for denying and concealing an already existing alcohol problem. Since not every drinker is aware of their addiction, and some people may react with denial or aggression, the diagnosis of the problem poses challenge. Most people believe that alcohol abuse is also a misunderstood social and cultural habit.

American research shows that problems with alcohol begin during legal studies. High anxiety levels and depression, alcohol abuse, frequent use of psychoactive substances, and difficulty coping with stress have been reported for law students (Reed et al., 2016).

The use of alcohol among law students was also investigated by one British university. More than two-thirds of firstand second-year students scored more than 8 in the Alcohol Use Disorders Identification Test (AUDIT) (World Health Organization: Take the AUDIT test now) - a score that indicates at least a risky drinking pattern. Furthermore, over

\section{WSTĘP}

$\mathrm{W}$ edług raportu Światowej Organizacji Zdrowia (World Health Organization: Global status report on alcohol and health 2018) w wyniku szkodliwego spożywania alkoholu umiera rocznie ponad 3 miliony ludzi (z których 75\% to mężczyźni). Oznacza to, że alkohol przyczynia się do 5\% wszystkich zgonów. Co bardzo istotne w kontekście zdrowia publicznego, szkodliwe spożywanie alkoholu jest odpowiedzialne za występowanie ponad 5\% chorób. Ponadto według cytowanego raportu spożywanie alkoholu w sposób szkodliwy i ryzykowny jest w krajach Unii Europejskiej trzecim najistotniejszym czynnikiem ryzyka pogorszenia stanu zdrowia i przedwczesnej śmierci. Z badań przeprowadzonych w Polsce wynika, że osoby uzależnione od alkoholu stanowią $2 \%$ populacji, a osób pijących szkodliwie jest 5-7\% (Moskalewicz et al., 2012).

Istnieje niewiele badań oceniających model spożywania alkoholu wśród prawników. Benjamin i wsp. (1990) w badaniach przesiewowych dotyczących adwokatów wskazali, że prawnicy borykają się z problematycznym spożywaniem alkoholu dwukrotnie częściej niż populacja ogółem. Kolejną próbę podjęto w badaniu ankietowym przeprowadzonym w Stanach Zjednoczonych - ryzyko uzależnienia, picia ryzykownego lub szkodliwego stwierdzono u 20,6\% adwokatów, co również sugerowało, iż badana grupa zawodowa jest bardziej narażona na uzależnienie niż populacja ogólna (Krill et al., 2016). Tran i wsp. (2007) wykazali, że wśród 486 francuskich adwokatów alkoholu nadużywało $11 \%$ mężczyzn i $6 \%$ kobiet - ponownie były to odsetki wyższe niż w populacji ogólnej.

Choć najnowsza z przywołanych prac pochodzi z 2016 roku, kwestia modelu spożywania alkoholu wśród adwokatów pozostaje w dużej mierze niezbadana. Przeprowadzono niewiele badań mających na celu empiryczną lub statystyczną weryfikację problemu, w szczególności zaś brakuje doniesień odnoszących się do polskich adwokatów.

Specyfika pracy prawników wymusza stresujące wystąpienia publiczne i częste spotkania towarzyskie, co stwarza liczne okazje do spożywania alkoholu. Dodatkowo atrakcyjność i prestiż zawodu mogą być przyczyną wypierania i ukrywania już istniejącego problemu $\mathrm{z}$ alkoholem. Zdiagnozowanie problemu nastręcza wiele trudności, ponieważ nie każdy pijący zdaje sobie sprawę z uzależnienia, a część osób reaguje wyparciem lub agresją. Zdaniem większości ludzi nadużywanie alkoholu jest też źle pojętym zwyczajem społecznym i kulturowym.

Według amerykańskich badań problemy z alkoholem zaczynają się już w trakcie studiów prawniczych. Dowiedziono, że studenci prawa cierpią z powodu wysokiego poziomu lęku i depresji, nadużywają alkoholu, często sięgają po substancje psychoaktywne i mają trudności z radzeniem sobie ze stresem (Reed et al., 2016).

Także na jednym z brytyjskich uniwersytetów zbadano sposób używania alkoholu przez studentów prawa. Ponad dwie trzecie studentów pierwszego i drugiego roku uzyskało w Alcohol Use Disorders Identification Test (AUDIT) 
other psychoactive substances in the past year. According to the authors of the study, psychoactive substance and alcohol abuse may affect the ability of some students to attend classes (Bogowicz et al., 2018).

Alcohol dependence among lawyers is also important from an epidemiological point of view as it may constitute a risk factor for many diseases.

This problem has not yet been the subject of research among Polish lawyers. Therefore, data on the scale of the problem are missing in Polish literature.

\section{AIM OF THE STUDY}

The aim of this study was to determine the model of alcohol consumption among lawyers, as well as the factors influencing this phenomenon.

\section{MATERIALS AND METHODS}

After obtaining the written consent of the Dean of the District Bar Council, its members were asked to complete an anonymous questionnaire, which included the AUDIT score and authors' original questions about factors that may influence the model of alcohol consumption. A total of 1,000 questionnaires were distributed. A total of 206 properly completed questionnaires were returned by 102 women and 104 men aged 29 to 84 years. Despite the wide age range and weekly working hours, all lawyers were professionally active and met the inclusion criteria.

The AUDIT screening, developed by Babor et al., based on a joint WHO project, as a screening tool for risky and harmful alcohol consumption (Saunders et al., 1993) was used to assess the probability of risky and harmful alcohol use.

The test contains 10 questions that cover three dimensions: addiction, risky drinking and harmful drinking. A score of 8-15 identifies a risky drinking pattern, a score of 16-19 indicates harmful drinking, and a score of $\geq 20$ indicates alcohol dependence. Each answer is scored 1 to 4 . Based on the obtained scores, we determined the model of alcohol consumption among lawyers.

Qualitative variables were characterised with numbers and percentage values. For quantitative variables, basic parameters of descriptive statistics, i.e. mean and standard deviation $(S D)$ were calculated, and minimum and maximum values were presented. Due to the size of the study group $(N=206)$, parametric methods were used to verify the hypotheses. Pearson's $r$ correlation coefficient (along with the significance test for $r$ ) was used to analyse the relationship between variables. Comparative analyses were preceded by the homogeneity of variance test, i.e. the Levene test. Since the assumption was not met, the Cochran-Cox test was used for comparisons between two groups, and one-way analysis of variance with Welch's correction was used for three groups. Tukey's HSD test was used for multiple comparisons. The results were considered statistically significant for $p$ values $\leq 0.05$. Statistica 10.0 package was used for calculations.
(World Health Organization: Take the AUDIT test now) powyżej 8 punktów - to wynik wskazujący na co najmniej ryzykowny model picia. Ponad jedna trzecia studentów pierwszego i drugiego roku prawa zgłosiła ponadto używanie innych substancji psychoaktywnych w ciągu ostatniego roku. Jak piszą autorzy badania, zdolność niektórych studentów do odbywania zajęć może być osłabiona w wyniku nadużywania substancji psychoaktywnych i alkoholu (Bogowicz et al., 2018).

Uzależnienie od alkoholu wśród adwokatów jest istotne również z epidemiologicznego punktu widzenia, może bowiem stanowić czynnik ryzyka wielu chorób.

Sygnalizowany tu problem nie był dotąd przedmiotem badań dotyczących polskich prawników. W rezultacie w krajowym piśmiennictwie brak jest danych na temat skali problemu.

\section{CEL PRACY}

Celami pracy były określenie modelu picia w grupie polskich adwokatów oraz zbadanie czynników wpływających na spożywanie przez nich alkoholu.

\section{MATERIA I METODY}

Po uzyskaniu pisemnej zgody Dziekana Okręgowej Rady Adwokackiej poproszono jej członków o wypełnienie anonimowej ankiety, która zawierała test AUDIT i autorskie pytania dotyczące czynników mogących mieć wpływ na model spożywania alkoholu. Adwokatom rozdano 1000 ankiet. Prawidłowo wypełnione kwestionariusze oddało 206 osób 102 kobiety i 104 mężczyzn - w wieku od 29 do 84 lat. Pomimo dużej rozpiętości wieku i tygodniowej liczby godzin pracy wszyscy adwokaci byli czynni zawodowo i spełniali kryteria włączenia do badania.

W celu oceny prawdopodobieństwa picia szkodliwego i ryzykownego lub uzależnienia od alkoholu użyto testu przesiewowego AUDIT, opracowanego przez Babora i innych na podstawie wspólnego projektu Światowej Organizacji Zdrowia jako narzędzie przesiewowe w zakresie niebezpiecznego i szkodliwego spożycia alkoholu (Saunders et al., 1993). Test zawiera 10 pytań, które dotyczą trzech obszarów: uzależnienia, picia ryzykownego i picia szkodliwego. Wynik z przedziału 8-15 punktów pozwala na rozpoznanie ryzykownego modelu picia, 16-19 punktów wskazuje na picie szkodliwe, a 20 punktów i więcej - na podejrzenie uzależnienia od alkoholu. Każda z odpowiedzi ma przyporządkowaną punktację od 1 do 4 . Na podstawie wyników uzyskanych przez badanych określono model konsumpcji alkoholu wśród adwokatów.

Zmienne jakościowe scharakteryzowano za pomocą liczebności i odsetków. W przypadku zmiennych ilościowych wyliczono podstawowe parametry statystyki opisowej - średnią i odchylenie standardowe (standard deviation, $S D$ ) oraz podano wartości minimalną i maksymalną. Z uwagi na liczebność badanej grupy $(N=206)$ hipotezy weryfikowano przy użyciu metod parametrycznych. Do analiz związku między 


\begin{tabular}{|c|c|c|c|c|c|}
\hline \multirow{2}{*}{\multicolumn{3}{|c|}{$\begin{array}{l}\text { Variable } \\
\text { Zmienna }\end{array}$}} & \multicolumn{3}{|c|}{$\begin{array}{c}\text { Respondents }(N=206) \\
\text { Badani }(N=206)\end{array}$} \\
\hline & & & $M \pm S D$ & & Min-max \\
\hline \multicolumn{3}{|l|}{$\begin{array}{l}\text { Age [years] } \\
\text { Wiek [lata] }\end{array}$} & \multicolumn{2}{|c|}{$43.07 \pm 11.81$} & $29-84$ \\
\hline \multicolumn{3}{|c|}{$\begin{array}{l}\text { Years spent in profession [years] } \\
\text { Liczba lat w zawodzie [lata] }\end{array}$} & \multicolumn{2}{|c|}{$15.22 \pm 11.41$} & $1-63$ \\
\hline \multicolumn{3}{|c|}{$\begin{array}{l}\text { Mean number of weekly working hours } \\
\text { Średnia liczba godzin pracy tygodniowo }\end{array}$} & \multicolumn{2}{|c|}{$50.53 \pm 10.37$} & $9-80$ \\
\hline \multicolumn{6}{|c|}{$\begin{array}{l}\text { Marital status } \\
\text { Stan cywilny respondentów }\end{array}$} \\
\hline \multicolumn{2}{|c|}{$\begin{array}{l}\text { Married: } 56.31 \% \\
\text { Mężatka/żonaty: } 56,31 \%\end{array}$} & \multicolumn{2}{|c|}{$\begin{array}{l}\text { Divorced: } 22.81 \% \\
\text { Rozwiedziona/y:22,81\% }\end{array}$} & \multicolumn{2}{|c|}{$\begin{array}{l}\text { Single: } 20.87 \% \\
\text { Wolna/y: } 20,87 \%\end{array}$} \\
\hline \multicolumn{6}{|c|}{$\begin{array}{l}\text { Children } \\
\text { Posiadanie dzieci }\end{array}$} \\
\hline $\begin{array}{l}\text { None: } 31 \% \\
\text { Bezdzietni: } 31 \%\end{array}$ & \multicolumn{2}{|c|}{$\begin{array}{l}1 \text { child: } 38 \% \\
1 \text { dziecko: } 38 \%\end{array}$} & \multicolumn{2}{|c|}{$\begin{array}{l}2 \text { children: } 28 \% \\
2 \text { dzieci: } 28 \%\end{array}$} & $\begin{array}{l}3 \text { children: } 3 \% \\
3 \text { dzieci: } 3 \%\end{array}$ \\
\hline
\end{tabular}

Tab. 1. Clinical characteristics of the study group

Tab. 1. Charakterystyka badanej grupy

\section{RESULTS}

The mean number of years spent in the legal profession in the study group was 15.22 years $(S D=11.41)$, and the mean number of working hours per week was $50.53(S D=10.37)$. The analysis took into account the marital status and the number of children owned by the respondents (Tab. 1).

The main aim was to assess the frequency of alcohol use in the group of lawyers. The analysis of the total score showed

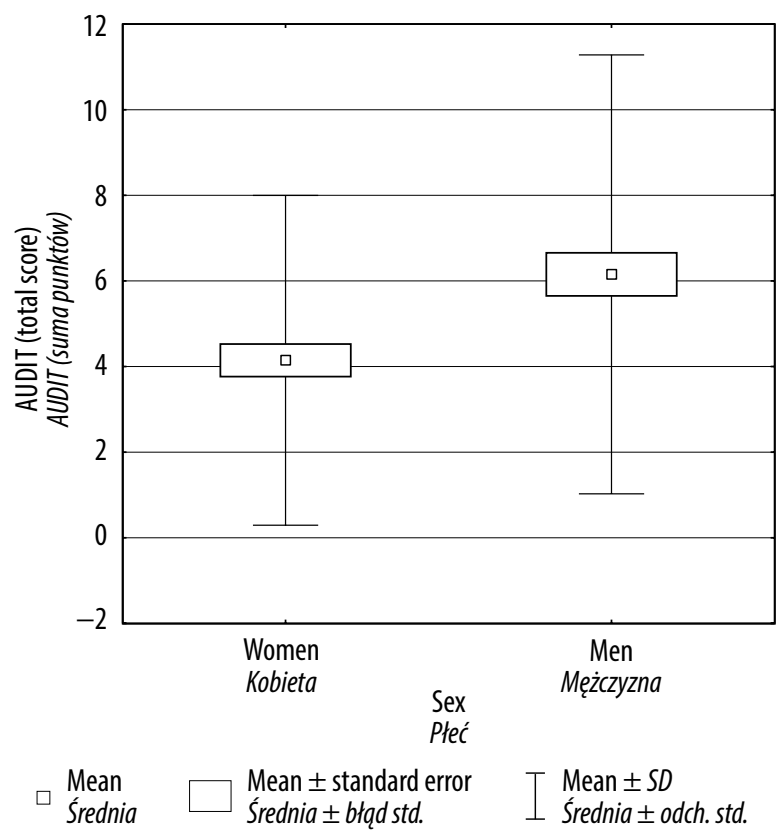

Fig. 2. Sex vs. total AUDIT score

Ryc. 2. Płeć adwokatów a wynik sumaryczny uzyskany $w$ skali

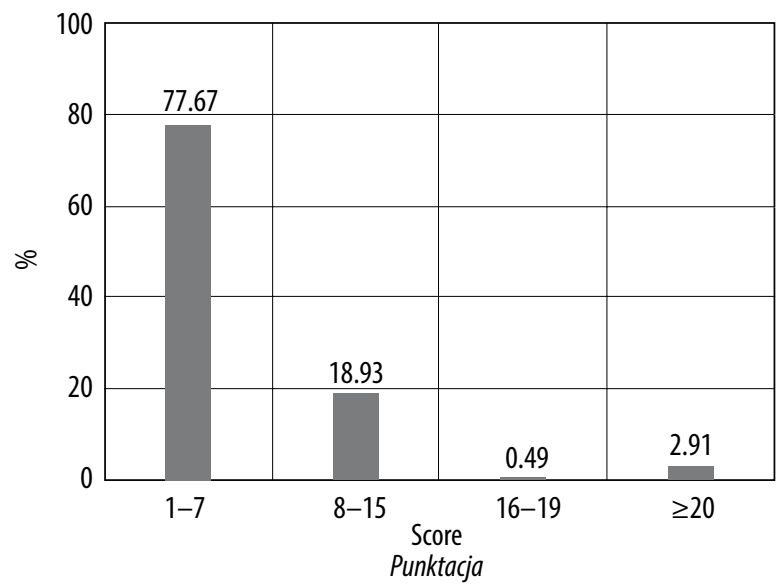

Fig. 1. The percentage distribution of AUDIT scores

Ryc. 1. Rozkład procentowy wyników w skali AUDIT

zmiennymi wykorzystano współczynnik korelacji liniowej $r$ Pearsona (wraz z testem istotności dla $r$ ). Analizy porównawcze poprzedzono badaniem jednorodności wariancji stosowano test Levene’a. Ponieważ założenie nie zostało spełnione, do porównań między dwiema grupami używano testu Cochrana-Cox, a w przypadku trzech grup - jednoczynnikowej analizy wariancji z poprawką Welcha. Do porównań wielokrotnych posłużył test HSD Tukeya. Wyniki uznawano za istotne statystycznie, gdy prawdopodobieństwo testowe $p$ spełniało założenie $p \leq 0,05$. Obliczenia wykonano w pakiecie Statistica 10.0.

\section{WYNIKI}

Średnia liczba lat w zawodzie adwokata wynosiła w badanej grupie $15,22(S D=11,41)$, a średnia liczba godzin pracy tygodniowo - 50,53 $(S D=10,37)$. W badaniu uwzględniono

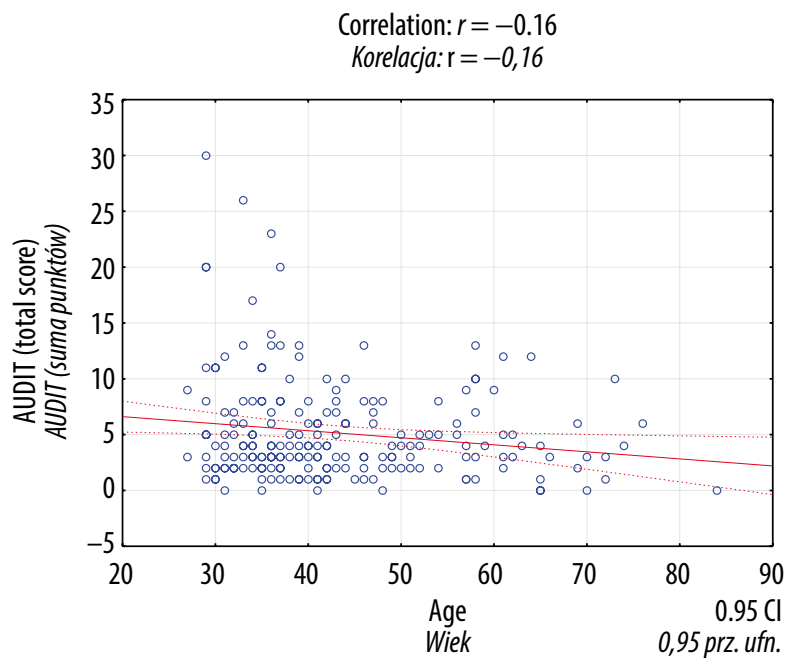

Fig. 3. The correlation between the age of respondents and the total AUDIT score

Ryc. 3. Korelacja między wiekiem badanych a suma punktów w skali AUDIT 


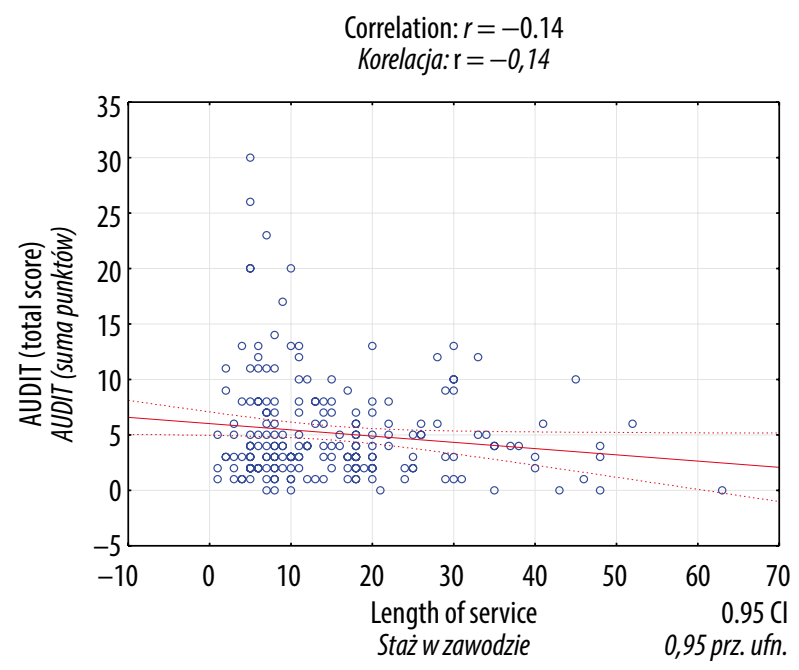

Fig. 4. The correlation between the length of service and the total AUDIT score

Ryc. 4. Korelacja między stażem pracy a wynikiem sumarycznym w skali AUDIT

that a score of $\geq 8$ was obtained by $22.33 \%$ of lawyers, with nearly $2.91 \%$ of respondents obtaining a score likely to suggest alcohol dependence (Fig. 1).

In the group of questions 1-3 on risky alcohol use, the scores obtained by $36.41 \%$ of the respondents indicated an alcohol problem. People at risk of alcohol dependence (questions 4-6) accounted for 3.88\% of the group, while harmful drinking (questions $7-10$ ) was reported for $10.19 \%$ of the respondents. Furthermore, 3.88\% of the respondents declared abstinence.

Another research goal was to analyse factors that influence alcohol consumption. The following variables were considered: gender, age, number of years in the profession, working time, marital status, and having children.

It was shown that the model of alcohol consumption differed depending on gender, with higher mean values obtained among men, and the difference was statistically significant (Cochran-Cox test, $p=0.002, t=-3.18$ ) (Fig. 2).

An analysis using the Pearson's $r$ correlation coefficient showed a statistically significant relationship $(p=0.021)$ between age and AUDIT score (Fig. 3). This was a lowstrength negative correlation $(r=-0.16)$, i.e. AUDIT scores decreased with the age of respondents.

Similar results were obtained in the case of years of service, with a correlation between an increasing number of years worked and a decreasing AUDIT score (Fig. 4).

There was no influence of weekly working hours on the alcohol use pattern $(p=0.169, r=0.10)$.

However, it was shown that the alcohol use pattern is influenced by both having children and the marital status of lawyers. A statistically significant (Cochran-Cox test, $p=0.000033$ ) relationship was found between having children and the AUDIT score, with lower AUDIT scores in lawyers who have children (Fig. 5).

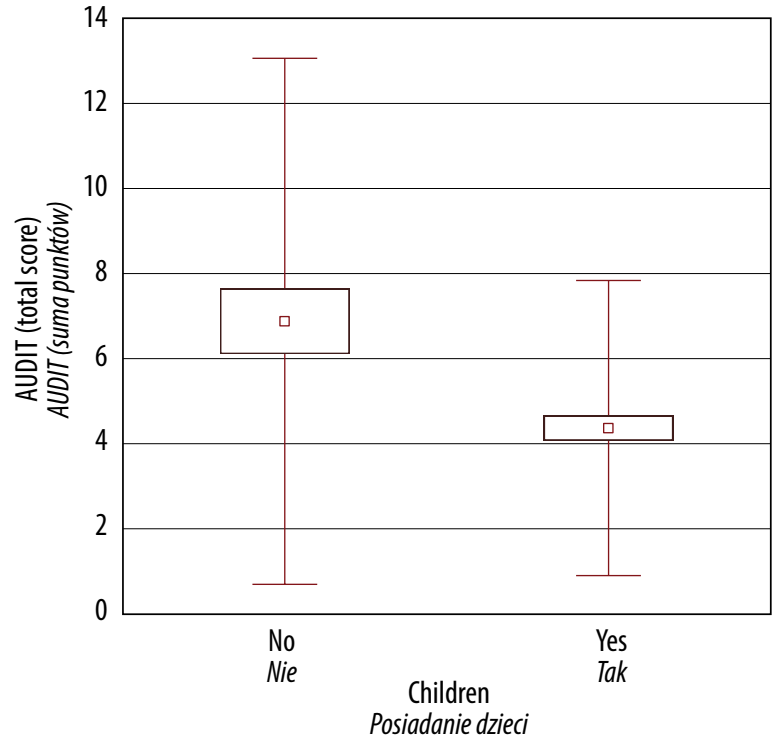

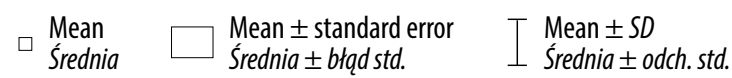

Fig. 5. The correlation between having children and the total AUDIT score

Ryc. 5. Posiadanie dzieci a wynik sumaryczny w skali AUDIT

stan cywilny i liczbę dzieci posiadanych przez respondentów (tab. 1).

Celem nadrzędnym była ocena częstości picia alkoholu w grupie prawników. Analiza ogólnej liczby punktów wskazuje, że 8 punktów i więcej uzyskało 22,33\% adwokatów, w tym u blisko $2,91 \%$ wynik może sugerować uzależnienie od alkoholu (ryc. 1).

W bloku pytań 1-3, odnoszących się do picia ryzykownego, wyniki wskazujące na problem uzyskało $36,41 \%$ ankietowanych. Osoby z ryzykiem uzależnienia od alkoholu (blok pytań 4-6) stanowiły 3,88\% grupy, a picie szkodliwe (pytania 7-10) dotyczyło 10,19\% badanych. Ponadto $3,88 \%$ ankietowanych deklarowało, że w ogóle nie pije alkoholu.

Kolejnym celem badawczym była analiza czynników mających wpływ na spożywanie alkoholu. Uwzględniono następujące zmienne: płeć, wiek, liczbę lat w zawodzie, wymiar czasu pracy, stan cywilny, posiadanie dzieci.

Wykazano, że płeć różnicowała model spożywania alkoholu - wyższe wartości średnich uzyskano wśród mężczyzn, a różnica była istotna statystycznie (test Cochrana-Cox, $p=0,002, t=-3,18$ ) (ryc. 2).

Analiza z wykorzystaniem współczynnika korelacji liniowej $r$ Pearsona wykazała istotny statystycznie związek $(p=0,021)$ między wiekiem a wynikiem w skali AUDIT (ryc. 3). Mamy tu do czynienia z korelacją o niskiej sile i ujemnym znaku $(r=-0,16)$, czyli wraz z wiekiem badanych spadała liczba punktów w AUDIT.

Podobne rezultaty uzyskano w przypadku stażu pracy w zawodzie: wraz ze wzrostem liczby przepracowanych lat malała liczba punktów w skali AUDIT (ryc. 4). 
One-way analysis of variance with Welch's correction showed statistically significant differences $(p<0.001)$ between the means in three groups: married, divorced and single respondents. Married lawyers scored lower in the AUDIT scale than divorced or single lawyers.

Multiple comparisons with the Tukey's HSD test in the version for unequal numbers confirmed the above conclusions. Significant differences were found between married and divorced attorneys $(p=0.011)$, as well as between married and single lawyers $(p=0.0110)$. However, no differences were found between divorced and single respondents $(p=0.993)$.

\section{DISCUSSION}

It may be suspected based on this screening study that Polish lawyers are at a greater risk of alcohol dependence than the general population. An AUDIT score of $\geq 8$ was obtained by $22.33 \%$ of lawyers, including nearly $3 \%$ of respondents with a score indicative of possible dependence. Meanwhile, a population study based on the Composite International Diagnostic Interview (CIDI), which was conducted by Moskalewicz et al. (2012), reported harmful alcohol use and alcohol dependence in $5-7 \%$ and $2 \%$ of the Polish population, respectively.

Our findings are comparable to those reported in other countries. US survey studies have shown that lawyers are more likely to develop alcohol dependence compared to the general population (Krill et al., 2016). In the US alone, $20.6 \%$ of lawyers surveyed had a score indicative of dependence, risky or harmful drinking.

In a French study, 1,282 lawyers were asked to complete the General Health Questionnaire (GHQ-28). In the study group, $16 \%$ of respondents reported alcohol abuse, with higher GHQ-28 scores in women (Tran, 2007).

The AUDIT score was higher in men in our study as opposed to some other publications. So far, studies among lawyers have emphasised that women are at a greater risk of addiction. Results similar to our findings, indicating a higher risk among women, were obtained in an American screening study, which included a group of 12,825 lawyers (Leignel et al., 2014).

In our research, the correlation between the age of respondents and the total AUDIT score showed that the score decreased with age, which corresponds with Krill et al. (2016) and Leignel et al. (2014).

According to Barani and Sabapathy (2015), the research data on alcohol habits among lawyers is very disturbing. The authors pointed out that a significant proportion of lawyers use alcohol on a daily basis, and almost half of them are smokers. It also turns out that female lawyers drink more during the week than their male colleagues. Only few female lawyers drink alcohol occasionally.

Contrary to our research, one early study in 1990 found a positive relationship between an increased prevalence of problematic drinking and more years spent in the legal profession (Benjamin et al., 1990). However, current
Nie stwierdzono wpływu tygodniowej liczby godzin pracy na model picia alkoholu $(p=0,169, r=0,10)$.

Wykazano natomiast, że na model picia wpływają zarówno posiadanie dzieci, jak i stan cywilny adwokatów. Dla zależności między posiadaniem dzieci a punktacją w skali AUDIT uzyskano wynik istotny statystycznie (test Cochrana-Cox, $p=0,000033$ ) - niższą punktację w AUDIT stwierdzono u adwokatów, którzy mają dzieci (ryc. 5). Jednoczynnikowa analiza wariancji z poprawką Welcha wykazała istotnie statystyczne różnice $(p<0,001)$ między średnimi w trzech grupach: mężatka/żonaty, rozwiedziona/ rozwiedziony oraz stanu wolnego. Prawnicy żyjący w związkach małżeńskich osiągali w teście AUDIT niższe rezultaty niż prawnicy rozwiedzeni lub single.

Porównania wielokrotne, dokonane za pomocą testu HSD Tukeya w wersji dla nierównych liczebności, potwierdziły powyższe wnioski. Istotne różnice występują między adwokatami żyjącymi w związkach małżeńskich a rozwiedzionymi $(p=0,011)$ oraz między prawnikami żyjącymi w związkach a prawnikami stanu wolnego $(p=0,0110)$. Nie stwierdzono natomiast różnic między osobami rozwiedzionymi a osobami stanu wolnego $(p=0,993)$.

\section{OMÓWIENIE}

Na podstawie badań przesiewowych można podejrzewać, że polscy adwokaci są narażeni na uzależnienie od alkoholu bardziej niż populacja ogólna. Osiem lub więcej punktów w skali AUDIT uzyskało 22,33\% adwokatów, w tym u blisko 3\% osób wynik może wskazywać na ryzyko uzależnienia. Tymczasem badania populacyjne oparte na Złożonym Międzynarodowym Kwestionariuszu Diagnostycznym (Moskalewicz et al., 2012) mówią o piciu szkodliwym u 5-7\% i uzależnieniu u $2 \%$ populacji polskiej.

Rezultaty badań własnych okazały się porównywalne do rezultatów z innych krajów. Z amerykańskich badań ankietowych wiadomo, że adwokaci są bardziej narażeni na uzależnienie od alkoholu niż populacja ogólna (Krill et al., 2016). W USA 20,6\% badanych adwokatów uzyskało wynik wskazujący na uzależnienie, picie ryzykownie lub szkodliwie. We francuskich badaniach udział wzięło 1282 prawników. Wypełnili oni Kwestionariusz Ogólnego Zdrowia dotyczący stanu zdrowia psychicznego (General Health Questionnaire, GHQ-28). W badanej grupie $16 \%$ osób zgłosiło nadużywanie alkoholu, a wyższe wyniki GHQ-28 występowały u kobiet (Tran, 2007).

Różnicą w stosunku do niektórych innych publikacji jest wyższy wynik w skali AUDIT uzyskany w prezentowanym tu badaniu przez mężczyzn. Dotychczas w badaniach prowadzonych wśród adwokatów podkreślano, że to kobiety są bardziej narażone na uzależnienie. Wynik podobny jak w badaniu własnym, wskazujący na wyższe ryzyko wśród kobiet, otrzymano w amerykańskich badaniach przesiewowych, które obejmowały grupę 12825 prawników (Leignel et al., 2014). W badaniach własnych korelacja między wiekiem uczestników a sumą punktów w skali AUDIT wskazała, podobnie 
alcohol consumption among lawyers in the first 10 years of practice (28.9\%). Lawyers practicing for 11-20 years come second $(20.6 \%)$. The above percentage values corresponded to what was agreed regarding the position held in a law firm. A total of $44 \%$ of respondents in the study group indicated that the problem began in the first 15 years of professional practice. Therefore, it is reasonable to suppose that the early stage of a legal career is strongly correlated with a high risk of alcohol abuse. The highest rates of problematic drinking were found among lawyers under the age of 30 years $(32.3 \%)$, followed by lawyers aged between 31 and 40 years $(26.1 \%)$. There was a decrease in indicators in the following years (Leignel et al., 2014).

Our research showed a protective effect of marriage and children, which corresponds with the common belief that family plays a supportive role in both healthy and therapeutic behaviours.

While some people use alcohol to deal with emotional problems, others may experience such problems as a result of drinking. It is difficult to say which scenario is more widespread or probable in the study population. The omnipresence of alcohol reflects both its high availability and social acceptance. Unfortunately, the health, social and work-related consequences of alcohol dependence are often irreversible. This study is the first attempt to assess alcohol use pattern among Polish lawyers. It may be concluded from our findings and other reports that it is necessary to support early diagnosis, intervention and therapy for alcohol dependence in the group of lawyers. The presented data show the need to increase resources for assistance programs, as well as to create effective preventive and therapeutic interventions tailored to the specificity of this profession. The confidential nature of assistance programs is important in order to overcome privacy concerns that can create a barrier between lawyers and professional assistance providers.

\section{CONCLUSIONS}

1. This study is the first medical assessment of the prevalence of alcohol use among Polish lawyers.

2. Lawyers are a professional group reluctant to undergo evaluation, who are at a high risk of problematic alcohol use.

3 . The screening study showed that $22.33 \%$ of lawyers were at risk of alcohol dependence, risky or harmful drinking.

4. Married lawyers with children reported lower average alcohol consumption, which indicated a protective role of the family.

5. Our findings show that there is a need for in-depth diagnosis of alcohol addiction and development of educational, preventive and therapeutic programs that take into account the specificity of the work of lawyers.

\section{LIMITATIONS OF THE STUDY}

Our study has some limitations. First of all, the lawyers were reluctant to consent for the questionnaire. Secondly, jak w badaniach Krilla i wsp. (2016) oraz Leignel i wsp. (2014), iż wraz z wiekiem liczba punktów maleje.

Jak piszą Barani i Sabapathy (2015), informacje uzyskane w trakcie badań nad nawykami alkoholowymi prawników są bardzo niepokojące. Autorzy zwracają uwagę na fakt, że znaczna część prawników pije alkohol nawet codziennie, a prawie połowa pali papierosy. Okazuje się, iż prawnicy częściej niż prawniczki piją w ciągu tygodnia. Tylko nieliczne prawniczki piją alkohol okazjonalnie.

Jedne z wczesnych badań, z roku 1990, wykazały pozytywny związek między większym rozpowszechnieniem problematycznego picia a większą liczbą lat spędzonych przez prawników w zawodzie (Benjamin et al., 1990), rezultaty były zatem odwrotne niż w badaniu własnym. Jednak we współczesnych badaniach amerykańskich dowiedziono, że prawnicy w ciągu pierwszych 10 lat praktyki uzyskują najwyższe wskaźniki szkodliwego picia alkoholu (28,9\%). Na drugim miejscu znaleźli się prawnicy praktykujący przez 11-20 lat (20,6\%). Powyższe wartości procentowe odpowiadały ustaleniom dotyczącym stanowiska zajmowanego w firmie prawniczej. W analizowanej grupie $44 \%$ osób wskazało, że problem zaczął się w pierwszych 15 latach praktyki zawodowej. Uzasadnione jest więc przypuszczenie, że wczesny etap kariery prawniczej silnie koreluje $\mathrm{z}$ wysokim ryzykiem zaburzeń związanych z używaniem alkoholu. Najwyższe wskaźniki problematycznego picia stwierdzono wśród prawników poniżej 30. roku życia (32,3\%), a następnie wśród prawników między 31. a 40. rokiem życia $(26,1 \%)$. W późniejszych latach odnotowano spadek wskaźników (Leignel et al., 2014).

W badaniach własnych wykazano ochronny wpływ małżeństwa i posiadania dzieci, co koresponduje z powszechnym przekonaniem o wspierającej roli rodziny zarówno w zachowaniach prozdrowotnych, jak i terapeutycznych.

Podczas gdy niektóre osoby piją alkohol, by poradzić sobie z problemami emocjonalnymi, inne mogą doświadczać takich problemów w wyniku picia. Trudno określić, który scenariusz jest bardziej rozpowszechniony lub prawdopodobny w badanej populacji. Wszechobecność alkoholu z pewnością świadczy zarówno o jego dużej dostępności, jak i społecznej akceptacji. Niestety, następstwa zdrowotne, społeczne i zawodowe uzależnienia od alkoholu często są nieodwracalne.

Niniejsza praca jest pierwszą oceną modelu picia alkoholu wśród polskich adwokatów. Biorąc pod uwagę wyniki otrzymane $\mathrm{w}$ badaniu własnym i doniesienia $\mathrm{z}$ innych badań, zdecydowanie należy wspierać wczesną diagnostykę, interwencję i terapię uzależnienia od alkoholu w grupie prawników. Prezentowane dane ukazują potrzebę zwiększenia zasobów na programy pomocy, a także stworzenia skutecznych interwencji profilaktycznych i terapeutycznych dostosowanych do specyfiki pracy prawników. Ważny jest tu poufny charakter programów pomocy, pozwalający przezwyciężyć obawy związane z prywatnością, które mogą tworzyć barierę między prawnikami a specjalistami gotowymi udzielić im wsparcia. 
it should be emphasised that the AUDIT is only for screening purposes. Estimates of problematic alcohol use do not allow for a conclusion that each of the participants with symptoms of alcohol abuse would meet the diagnostic criteria for addiction; the diagnosis requires clinical evaluation.

\section{Conflict of interest}

The authors do not report any financial or personal connections with other persons or organisations, which might negatively affect the contents of this publication and/or claim authorship rights to this publication.

\section{References / Piśmiennictwo}

Afuseh E, Pike CA, Oruche UM: Individualized approach to primary prevention of substance use disorder: age-related risks. Subst Abuse Treat Prev Policy 2020; 15: 58.

Barani G, Sabapathy P: Attitudes and health behavior of lawyers in Coimbatore, Tamil Nadu. ScientificWorldJournal 2015; 2015: 616719.

Benjamin GA, Darling EJ, Sales B: The prevalence of depression, alcohol abuse, and cocaine abuse among United States lawyers. Int J Law Psychiatry 1990; 13: 233-246.

Bogowicz P, Ferguson J, Gilvarry E et al.: Alcohol and other substance use among medical and law students at a UK university: a crosssectional questionnaire survey. Postgrad Med J 2018; 94: 131-136.

Krill PR, Johnson R, Albert L: The prevalence of substance use and other mental health concerns among American attorneys. J Addict Med 2016; 10: 46-52.

Leignel S, Schuster JP, Hoertel N et al.: Mental health and substance use among self-employed lawyers and pharmacists. Occup Med (Lond) 2014; 64: 166-171.

Moskalewicz J, Kiejna A, Wojtyniak B (eds.): Kondycja psychiczna mieszkańców Polski. Raport z badań „Epidemiologia zaburzeń psychiatrycznych i dostęp do psychiatrycznej opieki zdrowotnej EZOP Polska”. Instytut Psychiatrii i Neurologii, Warszawa 2012.

Reed K, Bornstein BH, Jeon AB et al.: Problem signs in law school: fostering attorney well-being early in professional training. Int J Law Psychiatry 2016; 47: 148-156.

Saunders J, Aasland O, Babor TF, de la Fuente J, Grant M: Development of the Alcohol Use Disorders Identification Test (AUDIT): WHO Collaborative Project on Early Detection of Persons with Harmful Alcohol Consumption-II. Addiction 1993; 88: 791-804.

Tran E, Limosin F, Caroli F et al.: Évaluation de la consommation d'alcool et du score au GHQ-28 chez 486 avocats du barreau de Paris. Encephale 2007; 33: 990-991.

World Health Organization: Global status report on alcohol and health 2018. World Health Organization, Geneva 2018. Available from: https://www.who.int/substance_abuse/publications/global_ alcohol_report/en/.

World Health Organization: Take the AUDIT test now. Available from: https://www.euro.who.int/en/health-topics/disease-prevention/ alcohol-use/do-you-drink-too-much-test-your-own-alcohol-consumption-with-the-audit-test/take-the-audit-test-now.

\section{WNIOSKI}

1. Prezentowane badanie jest pierwszą medyczną oceną rozpowszechnienia picia alkoholu wśród adwokatów w Polsce.

2. Adwokaci to grupa zawodowa, która niechętnie poddaje się badaniom, a zarazem grupa wysokiego ryzyka problemowego używania alkoholu.

3. W badaniu przesiewowym u 22,33\% adwokatów stwierdzono ryzyko uzależnienia od alkoholu, picia ryzykownego lub szkodliwego.

4. Wśród adwokatów żyjących w związkach małżeńskich i mających dzieci odnotowano niższe średnie spożycie alkoholu, co wskazuje na protekcyjną rolę rodziny.

5. Wyniki badań przesiewowych dowodzą, że istnieje konieczność pogłębionej diagnostyki w kierunku uzależnienia od alkoholu oraz stworzenia programów edukacyjnych, profilaktycznych i terapeutycznych uwzględniających specyfikę pracy prawników.

\section{OGRANICZENIA BADAŃ WŁASNYCH}

Prezentowane badanie ma pewne ograniczenia. Po pierwsze, prawnicy niechętnie wyrażali zgodę na wypełnienie ankiety. Po drugie, należy podkreślić, że skala AUDIT służy wyłącznie do badań przesiewowych. Szacunki problemowego używania alkoholu nie pozwalają na sformułowanie wniosku, że każdy z uczestników, u których stwierdzono objawy nadużywania alkoholu, spełniłby kryteria diagnostyczne uzależnienia - ustalenie rozpoznania wymaga oceny klinicznej.

\section{Konflikt interesów}

Autorki nie zgłaszaja żadnych finansowych ani osobistych powiazań $z$ innymi osobami lub organizacjami, które moglyby negatywnie wplynać na treść publikacji oraz rościć sobie prawo do tej publikacji. 